\title{
Introduction
}

\section{The Struggle for Self-Determination and the Palestinian Quest for Statehood}

\author{
Leila Farsakh
}

The quest for an independent Palestinian state has been at the core of the Palestinian national struggle for a very long time. It has been central both to the assertion of the Palestinian right to self-determination and to challenging Zionist attempts to erase the Palestine question. ${ }^{1}$ In 1971, the Palestine Liberation Organization (PLO) declared the creation of a democratic state in Palestine inclusive of Christians, Jews, and Muslims to be its goal and the only just solution to the Israeli-Palestinian conflict. In 1988, it went further by issuing the Declaration of Independence and having its chairman, Yasser Arafat, officially recognize Israel. This paved the way to the Oslo peace process in 1993 and implied that the Palestinian state was to be confined to the West Bank and Gaza Strip. By 2019, the state of Palestine was officially recognized by 137 states and admitted into the United Nations as a nonmember state. It remains, though, under occupation and is far from being independent or sovereign.

The aim of this book is to rethink the Palestinian state project and the challenges facing any alternative to it. It sheds new light on the ways in which the past three decades of peace process have transformed the meaning of Palestinian statehood and, with it, the solution to the Israeli-Palestinian conflict. As many have argued, the Oslo peace process reformulated, rather than ended, Zionist colonization, thereby undermining the possibility of a viable Palestinian state. ${ }^{2}$ Israel's continuous war and siege of Gaza, the presence of over 650,000 Israeli Jewish settlers in the West Bank (including East Jerusalem), the 708-kilometer Separation Wall and the institutionalization of over ninety-nine Israeli checkpoints have destroyed the two-state solution, long considered the only option for ending the IsraeliPalestinian conflict. Despite the Trump administration's 2020 peace plan, which put the final nail in the coffin of that solution, the Palestinian Authority, Hamas, and the international community remain committed to Palestinian national 
independence. ${ }^{3}$ The Arab Peace Initiative and the 2003 internationally sponsored Quartet Road Map to Peace consider the creation of such a Palestinian state not only a right but also the only means to end the Israeli-Palestinian conflict. ${ }^{4}$

Rethinking Statehood delves into the ways Palestinians are redefining the relationships among self-determination, decolonization, and political liberation today, given the territorial impossibility of a Palestinian state. The contributors, mostly young Palestinian scholars, move away from the conflict resolution approach that has dominated the peace discourse and the political science literature on Palestine. They provide instead a critical political perspective that situates the Palestinian state project within its regional context, rather than confining it to the limits of a narrow nationalist paradigm. At the same time, they go beyond the ongoing debate over the inevitability of a one-state solution or its political danger, by focusing on the political challenges Palestinians need to address in articulating an alternative to the present impasse. ${ }^{5}$ These include analyzing the extent to which Palestinian political rights, both collective and individual, can be protected outside the international consensus on partition as the paradigm for resolving the Palestinian-Israeli conflict.

In this regard, Rethinking Statehood engages with an emerging trend in Palestine studies that advocates for breaking out of national frames to understand the Palestine question. ${ }^{6}$ Its main contribution lies in examining the opportunities and costs of moving away from the pursuit of territorial sovereignty as a means to achieve political liberation. As this introduction argues, the quest for a Palestinian state was not in vain, but its historical role has come to an end. It is thus necessary to reexamine this role and explore how the failure of national independence enables us to rearticulate the relationship between self-determination and decolonization away from the telos of the nation-state. Such a rearticulation requires transcending the partition paradigm that has dominated all international attempts to resolve the Israeli-Palestinian conflict. It entails defining the elements of a political alternative that is democratic, viable, and economically feasible. It also must address the question of Zionism and explain how the political rights of Jewish Israelis can be reconciled with Palestinian rights in any attempt to decolonize the ongoing settler-colonial reality.

\section{SELF-DETERMINATION AND STATEHOOD}

At the heart of the Palestinian struggle is a yearning to return home and for freedom-freedom from settler-colonialism, as much as from oppression and exile. ${ }^{7}$ Ever since they were expelled from their land during the 1948 war and the creation of the State of Israel, Palestinians have sought to fulfill their right of return, which is enshrined in UN Resolution 194, issued on December 4, 1948. The establishment of the PLO by the Arab League in 1964 reaffirmed this right, as its charter called for the liberation of Palestine from Zionist imperialism. The PLO charter 
did not specify statehood as part of its mission, though, since it envisaged Palestine as part of a larger Arab collectivity. It was only in the aftermath of the 1967 Six Days War and the international consensus on UN Security Council (UNSC) Resolution 242 as a framework for peace in the Middle East that the Palestinian national movement made the project of an independent state the vehicle for decolonizing Palestine from Zionism and affirming the Palestinian right to self-determination.

In this regard, the Palestinian national movement was not much different from most anticolonial liberation movements of the twentieth century. Selfdetermination, a concept internationalized with Lenin's defense of people's right to national independence and reframed by Wilson's Fourteen Points in 1918, laid the foundation of a twentieth-century world order composed of nation-states. ${ }^{8}$ By 1960, it became "the juridical component of international non-domination," as Adom Getachew put it. ${ }^{9}$ Yet, as she and others have shown, self-determination was a concept used by imperial powers to reorganize their spheres of control, as much as it was claimed by every national liberation movement demanding freedom from colonialism. Imperial powers viewed it a principle that colonized people could exercise once they prove fit to do so, thus tying it to imperial racial and political considerations. Anticolonialists, on the other hand, defined self-determination as an inalienable right to achieve freedom from external domination. ${ }^{10}$

UN Resolution 1514, adopted in 1960 by the UN General Assembly (UNGA), affirmed the status of self-determination as a human right, one that is necessary in order to fulfill all other rights. It also declared colonialism a crime and specified that "all people have an inalienable right to complete freedom, the exercise of their sovereignty and the integrity of their national territory." ${ }^{11}$ It thus inadvertently made self-determination synonymous with national territorial sovereignty, that is, statehood. ${ }^{12}$ While many were aware of the inherent contradiction of the nation-state as protector as well as violator of human rights, an international consensus had formed around the necessity of independent statehood as a first, if not sufficient, step towards political liberation. This is because the nation-state was conceived as the internationally recognized sovereign entity that ensures citizens their political rights, including their right to security and protection from external domination.

For many anticolonialists, though, the creation of an independent state was not the only, or optimal, means to guarantee people's freedom and their national sovereignty. They considered the right to self-determination as a people's right to define their political future and choose their political form, or system, of government for managing their affairs. It did not need to be territorially bound, since sovereignty is enshrined in the people, or the nation, not in the state per se. Instead it can be fulfilled through various political configurations, such as transforming empires into representative federations, or confederations, of equal citizens. As Wilder and Getachew have shown, anticolonial proponents of the right to selfdetermination envisaged its implementation as part of a larger project of remaking the world beyond the Westphalian order of sovereign states, one that required 
transforming political and economic structures, both domestically and internationally, in ways that would guarantee the freedom and equality of all people. ${ }^{13}$ They were cognizant of what revolutionaries from Toussaint Louverture to Fanon have warned against, namely that national independence does not guarantee liberation, for it can create new forms of domination that deny citizens their political and economic rights.

The Palestinian struggle for self-determination carried within it this ambiguity concerning the relationship between national liberation and statehood. As Edward Said put in 1978, the PLO never resolved "the question of whether it is really a national independence or a national liberation movement." ${ }^{14}$ Since the arrival of Fatah at the head of the PLO in 1968, the Palestinian national discourse has tied return with liberation and conscripted the notion of self-determination to the right to establish an independent Palestinian state. In 1971, the eighth Palestinian National Council (PNC) convention adopted a unanimous resolution specifying that "the armed struggle of the Palestinian people is not a racial or religious struggle directed against the Jews. This is why the future state that will be set up in Palestine liberated from Zionist imperialism will be a democratic Palestinian state. All who wish to will be able to live in peace there with the same rights and the same duties." 15 What came to be known as the Palestinian version of a one-state solution was presented as the means to protect Palestinian political rights by affirming the right to an independent, decolonized nation-state. It asserted Palestinian political existence in the face of international denial, as best exemplified with UNSC Resolution 242. This resolution, adopted on November 22, 1967, acknowledged the right of each state in the region to "live in secure and recognised boundaries." It did not, though, mention the Palestinians nor any of their UN-protected rights, such as those detailed in UN Resolutions 181 and 194. It simply referred to them as refugees in need of a humanitarian solution, not a national group with a right to self-determination. ${ }^{16}$

From its inception, the Palestinian state project was a project of national selfaffirmation as well as of political actualization. Its aim was to assert Palestinian "peoplehood" which Zionism sought to eradicate, as much as to articulate a just political future inclusive of all those who live on the land. While many doubted the sincerity of its inclusive vision, which Israel outrightly rejected, Palestinian nationalists were clear about opposing Zionism as a racial colonial project of domination rather than rejecting Jews for their identity. The PLO's diplomatic and legal efforts in this regard came to fruition in 1974 with UNGA Resolution 3236, which affirmed the legitimacy of Palestinian anticolonial struggle and right to "national independence and sovereignty." In UNGA Resolutions 3236 and 3237, the international community-as represented by the UN-also recognized the PLO as the sole legitimate representative of the Palestinian people and invited it to participate in the works of the General Assembly like any nonmember state, such as the Vatican. ${ }^{17}$ The PLO, meanwhile, acted as a state in exile, with its various political 
institutions, electoral structures, and economic services, representing and providing for Palestinians in the diaspora as well as for those under Israeli occupation. ${ }^{18}$

Linking self-determination with statehood, in other words, gave the Palestinian revolution a concrete political meaning in an international system that recognized the legitimacy of decolonization struggles in the post-WWII era and bestowed on states the primary responsibility of representing and protecting the human and political rights of citizens. What remained contested within the Palestinian national movement was the content and shape of this state, as much as the extent to which its creation would be the means to, or the end of, decolonization.

By 1974, the PLO gave up on the idea of remaking the regional and international order of nation-states and defeating imperialism. It accepted instead the confines of realpolitik and the international consensus on UN Resolution 242, which it officially recognized in 1988. In 1974, the twelfth PNC adopted the Ten Points transitional program, which became known as the pragmatic, or step-by-step, route to decolonization. It specified that "the PLO will employ all means . . . . for the liberation of Palestinian land and setting up a patriotic, independent fighting national authority in every part of the Palestine territory that will be liberated .... The PLO will consider any step toward liberation which is accomplished as a stage in the pursuit of its strategy for the establishment of a democratic Palestinian state."19 Although many contested the possibility of a Palestinian state without fully dismantling Zionism, the majority accepted the view that national independence was a first step towards national liberation. This view gained further strength after Israel's war against the PLO in Lebanon in 1982 and the failure of the Arab states to come to the rescue of the Palestinians. The PLO's Declaration of Independence in 1988, announced in the wake of the First Intifada, which erupted in the Gaza Strip and the West Bank in December 1987, represented the official Palestinian acceptance that national self-determination could only be fulfilled on part of historic Palestine, and that it is attainable by negotiating with, rather than defeating, Israel. ${ }^{20}$

The Palestinian state project thus became the price for the Palestinian historic compromise with Israel. Herein too lies its historical importance. It was the only way for the Palestinians to advocate for themselves at any peace negotiations bounded by the parameters of the international consensus on partition as the solution to the Arab-Israeli conflict as set out in UN Resolution 181, and more specifically by UNSC Resolution 242. A Palestinian state on only 22 percent of Palestine was considered better than no state, because it promised political independence. It offered recognition and a historical compromise with an enemy, even if it could not bring about full liberation. It allowed a means for the return of the refugees, even if it could not restore justice to the Palestinians for the Nakba. Above all, it promised citizenship rights to Palestinians denied of these rights, whether in the diaspora or under Israeli occupation. In other words, the Palestinian state project affirmed the Palestinian "right to have rights" to quote Arendt. ${ }^{21}$ 


\section{PALESTINIAN STATEHOOD AND THE OSLO \\ PEACE PROCESS}

The Oslo peace process in 1993 provided an opportunity for the Palestinian national movement to reap the fruits of Palestinian resistance by territorializing the dream of a Palestinian state, at least from the point of view of the PLO leadership. With the signing of the Declaration of Principles in 1993 and Interim Agreement on the West Bank and Gaza Strip in 1995, the PLO acquiesced to a conflict resolution approach intrinsically tied to the concept of territorial partition as a paradigm for achieving a minimum of Palestinian rights. It accepted Israel's insistence that the starting point of the conflict was the 1967 war-not the 1948 war. Although fully aware that the Oslo peace process did not end the occupation or specify as its end goal the creation of a Palestinian state, the Palestinian leadership remained committed to proving that Palestinian statehood was both necessary and achievable. It was bolstered by international community support in this regard, especially as expressed by the Arab Peace Initiative in 2002 and the Quartet Road Map to Peace in 2003 .

Starting with Arafat's return to Gaza in 1994 and role as the head of a democratically elected Palestinian National Authority (PNA) in January 1996, the Palestinian official narrative shifted from decolonization to state-building. The PNA focused on behaving as a state in order to be recognized as one, embarking on a wide variety of activities that ranged from setting up a new police force and various ministries and ritualizing presidential salutes and national anthems while receiving foreign ambassadors, to devising national development strategies and filing petitions against Israel's separation barrier to the International Court of Justice (ICJ) in 2005. Such performances of statehood sought to abstract the reality of occupation, not so much in order to deny it but rather to refuse to be constrained by it. They were not simply acts of "make believe," even if they appeared at times delusional. They were rather attempts to affirm Palestinian agency and legitimate national existence despite Israel's continuous obstructions, a legitimacy recognized by the international community, which admitted the State of Palestine into the UN in 2012, as well as into the UNESCO, International Criminal Court, and other international fora.

The PNA's belief that national independence was attainable through statebuilding in the present, rather than by revolutionary armed struggle resistance as in the past, was best exemplified by the Fayyad technocratic government in 2007. This government, which was set up in the aftermath of the international boycott of Hamas's electoral victory in 2006 and the Fatah-Hamas debacle in June 2007, defined its mission as providing "the final push to statehood." ${ }^{22}$ It worked on proving Palestinian institutional readiness for independent statehood by laying the foundation of a modern state, as advised by PNA's new international sponsors, the World Bank and International Monetary Fund. It confined the meaning of selfdetermination to the establishment of a neoliberal state, as defined by Washington's 
conception of good governance. State-building thus became about law and order, not about national unity or democratic representation. Its mission was to foster "institution-building" and fiscal transparency in order to ensure the development of a vibrant private sector. It was sustained by the creation of large bureaucracy who produced, as much as depended on, the institutional edifice of this neoliberal state. ${ }^{23}$ State-building implied that the PNA was performing "a kind of statehood not based on sovereignty but on management of financial resources and credible claims to management of an uncertain future." ${ }^{24}$

More assiduously, this state-building effort proved to be a site of governance and control. It became an effort by which the PNA shaped power relations over space and people, rather than a strategy that could effectively halt Israeli settlement construction, end the siege on Gaza, or bring liberation. This was visible at the macro level, in the creation of a repressive police force and prison system in the West Bank and Gaza Strip and in the failure to create independent and transparent judiciary. It also was clear in the way state-building efforts reshaped access to resources and power at the micro level, whether in developing the housing and land markets, encouraging public-private partnerships, or setting up the infrastructure for a modern electricity grid and road system. As a new generation of scholars have demonstrated, the development of modern electricity grids, new housing projects, or even "national environmental policies" does not only highlight the PNA's attempt to affirm a certain sovereign modernity. ${ }^{25}$ Such projects also reflect the kind of polity the PNA is seeking to create, one that promotes a transactional, individualized relation between the central authority and the Palestinian population, rather than encourages collective representations and accountability. This state-building apparatus inevitably produced a political entity that was increasingly authoritarian, serving mostly an emerging private sector tied to the PNA and international capital. The PNA became unable, or unwilling, to undo the settler-colonial reality, given how embedded it was with safeguarding Israeli security through the Oslo peace agreement and its state-building efforts.

With the signing of the Oslo peace accords, the historical role of the Palestinian state project for the Palestinian cause was thus bound to come to an end. This was confirmed with the failure of the final status negotiations, after the Camp David Summit in 2000, to bring about Palestinian territorial independence, despite all the compromises that the Palestinian Authority was willing to make towards Israel. ${ }^{26}$ The pursuit of a state had been essential for achieving Israeli and international recognition of the Palestinians as a collective, or national, political entity. However, Israel's recognition of the PLO had proved to be a means to fragment the Palestinian people and undermine their right to self-determination. Attempts to counter this fragmentation remained ineffective because the Palestinian leadership, the international community, and the regional powers all remained committed to partition as the only way to achieve Palestinian independence. The PNA's insistence that the problem is not partition in itself, but in the lack of implementation of UN 
resolutions did not carry much sway since the international community proved unwilling to exert pressure on Israel to retreat fully from the West Bank and Gaza or even to adhere to the terms of the Oslo agreements.

Indeed, it is impossible to explain the persistence of the Palestinian state project, as much as its failure, without considering the international investment in it. ${ }^{27}$ The Quartet on the Middle East (UN, European Union, United States, Russia) has been the major advisor and funder of the Palestinian state project, dispersing over twenty-seven billion dollars to the Palestinian territories since 1994, making the Palestinian Occupied Territories one of the world's largest recipients of aid per capita. ${ }^{28}$ Although the international community has been frustrated with Israel's continuous construction of settlements and its violation of Palestinian human rights, its approach has been to reform, rather than reject, the principle of partition. It focused its energy on improving the PNA's institutional capability to prove Palestinian readiness for political independence, giving special attention to enhancing the PNA's monopoly over the use of violence in the West Bank and Gaza. The international community thus restricted the meaning of statehood to the power of an internationally recognized authority to impose law and order over a specific population. It did not tie it to fostering democratic accountability or ensuring Palestinian unity, let alone adhering to international law or forcing Israel to withdraw from Palestinian land. ${ }^{29}$ It ignored the importance of territorial contiguity for the physical viability of any state by prioritizing Israel's security concerns in delineating the extent of Palestinian territorial and demographic jurisdiction.

In acquiescing to the prioritization of Israeli security demands, the international community and the PNA thus contributed to transforming the Palestinian state project from a vehicle for national independence to a regionally and internationally sponsored endeavor to dissolve the Palestine question. Juridically, the Palestinian state project under Oslo confined the Palestinian nation to the West Bank and Gaza Strip. It thus compromised the unity of the Palestinian people and the political rights of those Palestinians not included in the new territorial nationstate, that is, the Palestinian citizens of Israel and refugees, who are at the crux of the Palestinian question. It also undermined the national Palestinian political system with the creation of new territorially confined political bodies, namely the PNA and the Palestinian Legislative Council. These political entities de facto superseded the Palestinian Liberation Organization and its Palestinian National Council, the bodies that had historically represented Palestinians both inside and outside the West Bank and Gaza Strip..$^{30}$ The Palestinian national collective, or "we," was thus compromised, especially as no new encompassing entity was created to represent and reunite all Palestinians as the PLO had before 1993.

The territorialization of the Palestinian dream of national self-determination has thus been emptied of any emancipatory potential. Rather than undo the unequal power relations imposed by Israel and the international order, the project of statehood introduced instead new structures of domination that perpetuate, 
rather than dismantle, the settler-colonial reality Palestinians are forced to endure. The Palestinians living in the West Bank and Gaza are effectively living in a onestate condition, with Israel as the only sovereign a reality that has been increasingly described as apartheid. ${ }^{31}$ The entrenchment of the PNA's authoritarian regime and its refusal to revive the PLO or hold elections have compromised Palestinian citizenship rights. ${ }^{32}$ Meanwhile, the PNA's obsession with statehood risks reducing the Palestinian struggle to a humanitarian problem once again; Palestinians leaders are now more focused on finding means to combat Covid-19 and prevent poverty levels from rising further in the Gaza Strip while keeping a captive economy afloat through international aid. They are not focused on ensuring an inclusive national debate on how to protect Palestinian rights in the face of continuous Israeli colonial onslaught, as seen in the latest war on Gaza in 2021.

\section{RETHINKING DECOLONIZATION, \\ TRANSCENDING PARTITION}

If the past fifty years of Palestinian struggle prove that the quest for a Palestinian state was necessary to affirm a people's collective political existence, they also indicate that the pursuit of statehood can compromise national rights, especially when such a state is confined to an international neoliberal understanding of political sovereignty. The experience of the past fifty years makes it clear that national independence cannot be achieved through partition or in a context of ongoing Zionist colonization. As Dubonov and Robson have most recently argued, partition plans are intrinsic to imperial strategies to divide and conquer. ${ }^{33}$ They have been proposed to "resolve" ethnic or national conflicts by steering ethnic or national groups into divided spaces. However, they have not succeeded in bringing about enduring peace, let alone reconciliation between conflicting parties, whether it is between Hamas and Fatah, Israel and the Palestinians, India and Pakistan, or the UK and Northern Ireland, among other examples.

The crisis that the Oslo peace process created for the Palestinian national cause has led to a renewed call for a return to the original tenets of the Palestinian political struggle, namely its commitment to liberation from settler-colonialism. The question that took hold of Palestinian activists and academics became how to think of "liberation beyond the not yet fully realised and yet already mutilated project of the nation-state." ${ }^{34}$ This did not mean that the "national as a horizon of liberation" has lost its importance, as Salih and Richeter-Devroe put it, but rather that it has become a more contested space, since people in the Occupied Territories and in the diaspora questioned the PNA's attempted monopoly at defining the contour and content of this nation. A new discourse started to emerge, focused on articulating the elements of a new political strategy able to unite the Palestinian body politic and protect Palestinians rights. Such a strategy unequivocally rejects partition as a solution and relies on settler-colonialism as an analytical paradigm 


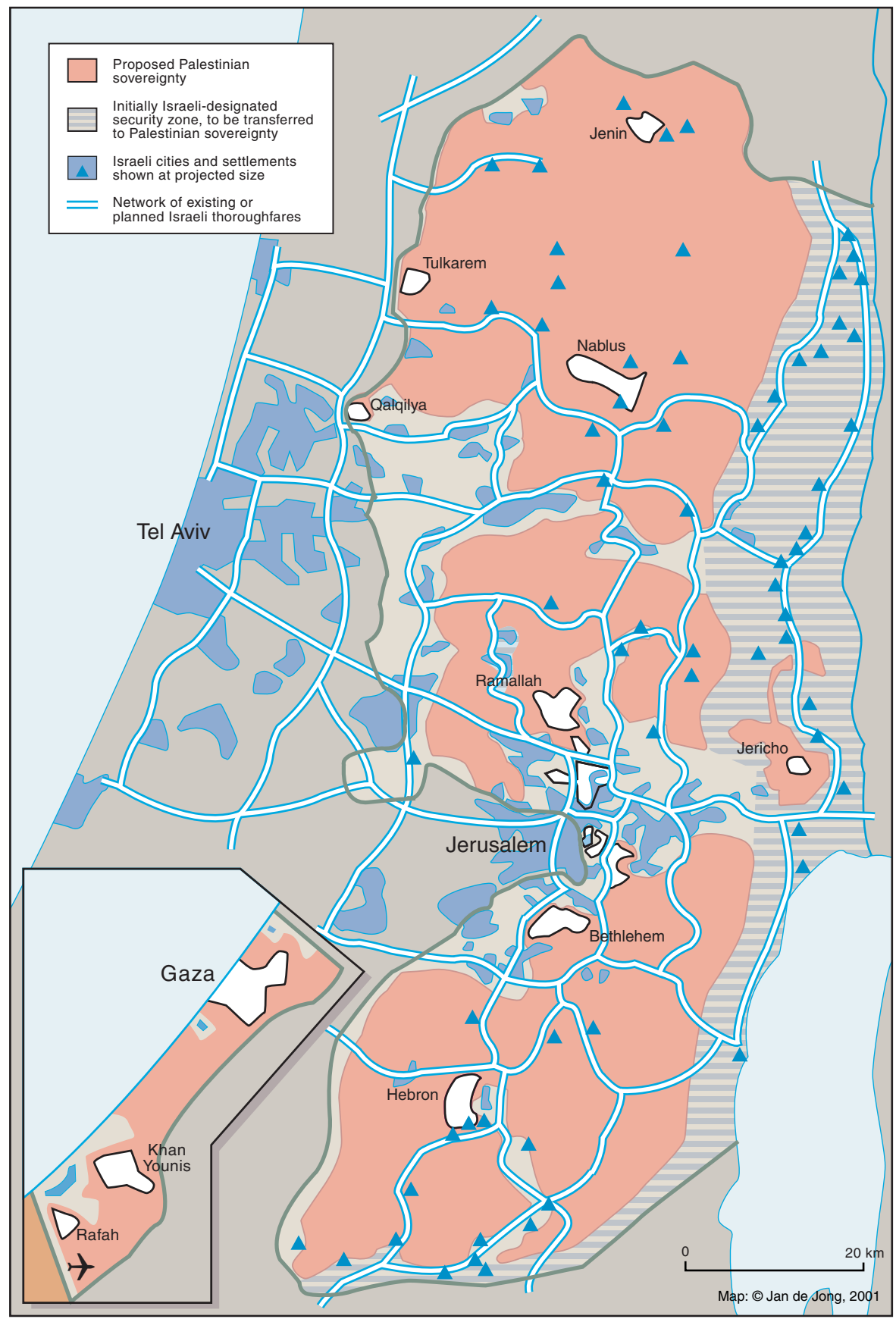

MAP 5. Scope of Palestinian sovereignty proposed at the Camp David Summit, 200o. Source: Palestinian Academic Society for the Study of International Affairs. 


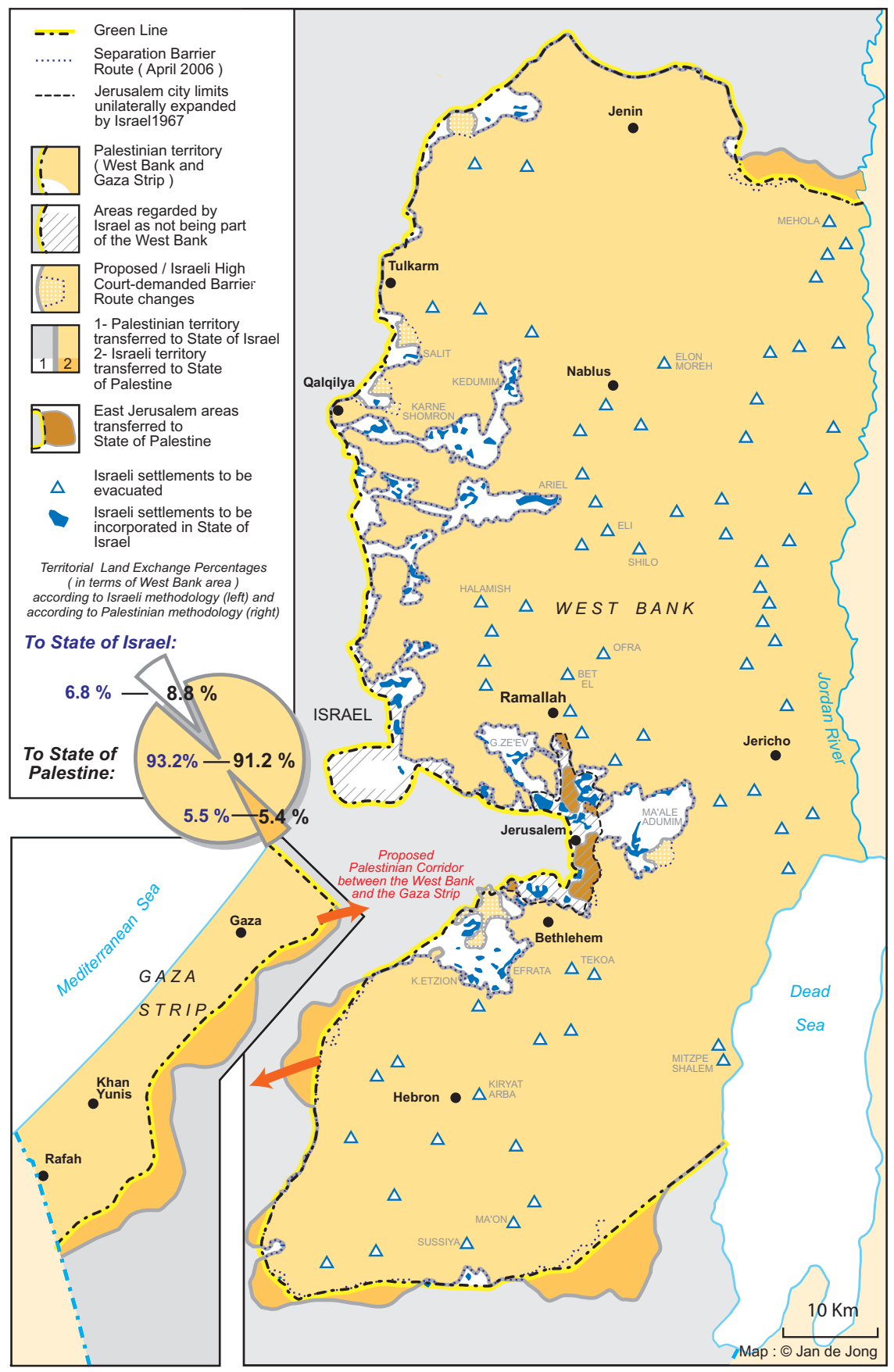

MAP 6. The Separation Wall and boundaries of the Palestinian state according to the Olmert Peace Plan, 2008. Source: Palestinian Academic Society for the Study of International Affairs. 
for understanding the Israeli-Palestinian conflict. ${ }^{35}$ It seeks to transcend an ethnic and territorial understanding of self-determination, that is, the framework of the exclusive nation-state, and to propose a political alternative that protects the individual and collective rights of citizens.

Since the failure of the Camp David negotiation in 2000, Palestinian academics and activists have become more vocal about how Israel reformulated, rather than ended, its colonial rule. They have highlighted, in particular, how Oslo's institutionalization of the demographic separation between Israelis and Palestinians through territorial fragmentation and annexation of Palestinian land has not only violated Palestinian rights but also made any solution based on partition racially delineated and unequal. The Oslo peace process, and the partition paradigm on which it was based, avoided dealing with Israel's colonial foundation, for it was premised on the principle that the only way to affirm Palestine's political existence is to acknowledge Israel's. This proved to be a real trap for the Palestinian leadership, given Israel's insistence on being recognized as a Jewish state in any final status peace agreement. Palestinians cannot acquiesce to such a demand, for it would deny their political existence and their right to the land.

The revival of settler-colonialism as an analytical framework has also been accompanied by a discursive shift away from the pursuit of statehood and towards Palestinians' inalienable rights. This rights-based approach has gained prominence with the ICJ ruling against Israel's wall in 2005 and the rise of the Boycott, Divestment and Sanctions (BDS) movement. It sees in international law a potent tool for holding Israel accountable to its international obligations and for protecting the unity of Palestinian rights, including the right of return, freedom from occupation in the West Bank and Gaza, and the right to equal citizenship for the Palestinians living inside Israel. The BDS movement has been particularly effective in mobilizing support for new strategies of nonviolent resistance as an alternative to the violence of the Second Intifada, which became demonized in a post-9/11 world. It has helped to show the continuity of Israeli settler-colonial policies that violate Palestinian rights and to generate a growing international solidarity with Palestinians at the grassroots level and in different policy circles (such as local governments, unions, and churches, et cetera).

The rights-based discourse, however, has not been sufficient for articulating a political alternative to the present political impasse. The BDS movement, for example, does not take a position on whether the Palestinians should abandon the pursuit of a state. It also does not take a position on the international legal consensus on partition or offer an alternative to it. According to some critiques, the rights-based approach risks, albeit inadvertently, individualizing the Palestinian struggle by focusing on Palestinian individual human rights. ${ }^{36}$

Attempts to redress this problem have focused on affirming the unity or nationhood of Palestinian people, albeit by proposing two different approaches. The first rejects the very idea of a Palestinian state as a political aspiration. Led mainly by 
anthropologists and historians, this approach calls for transcending nationalist frames, given that such frames prioritize the creation of a state over the Palestinian people. ${ }^{37}$ It considers the state a site of inherent violence and thus bound to be oppressive, especially in the absence of a free and active civil society. It emphasizes that sovereignty lies with the people, not with the state, and highlights that globalization has undermined the importance of territorial sovereignty. Politically, this approach affirms the political agency of the Palestinians everywhere, not just in the Occupied Territories. It embraces the fragmented and exilic Palestinian experience rather than negates it, as the state project tried to do.

This anti-statist approach has gained traction in the diaspora promoted among Palestinians living in Western societies. While this discourse may sound reminiscent of the PLO's original prioritization of return over statehood, its main focus is on redefining the relationship between identity and place beyond the territory of the nation or the boundaries of the state. In this regard, the anti-statist critique of the Palestinian state project provides a resounding rejection of the PNA attempt to monopolize who the Palestinian collective, or "we," is. It gives space to counternarratives created through Palestinian grassroot initiatives to reclaim the public sphere by challenging hegemonic power structures. Yet this anti-statist critique does not solve the political and humanitarian problems of those living with no legal protection or citizen rights in Lebanon or Syria, for example. It also overlooks the fact that vibrant autonomous public spheres usually exist only in democratic societies where residents have the legal and political tools to challenge state violence and where state power is both limited and circumscribed by law. This antistatist critique remains pertinent, though, insofar as it highlights the importance of taming state power by emphasizing the creation of representative counterpowers and the protection of spaces for public engagement. It is helpful in pointing out the importance of defining the kind of political community, or polity, that the struggle for self-determination seeks to create in order to ensure that it does not compromise its people's rights.

The second approach for reaffirming Palestinian national rights does not bypass the state. It rather considers the one-state solution the only means to decolonize Palestine. ${ }^{38}$ Most of the critical writings by political scientists, legal scholars, and activists over the past twenty years have revolved around defining the political shape, and ethical value, of such a state. There is no consensus, however, on whether such a state should be a liberal democratic state or a binational one. Defenders of the former remain fundamentally attached to the importance of Palestinian territorial sovereignty over the whole of Palestine. They are committed to the principle of individual political equality between all the inhabitants of the land while emphasizing the indigenous sovereignty of the Palestinian people. According to Abunimeh (2014), Israeli Jews living in Palestine have legitimate individual political rights as equal citizens, but not a collective, or national, right to self-determination: this is largely because whenever they have had such 
a right, it has come at the expense of the Palestinians. Abunimeh and others reject binationalism as an option since, in their view, it entails an endorsement, however oblique, of Zionism and thus of colonialism. ${ }^{39}$ The 2018 Israeli nationality law, which bestowed the right to self-determination in the whole area Israel controls only to the Jews, is a case in point. According to Omar Barghouti, a democratic state in all of Palestine offers the only ethical solution to the Israeli-Palestinian conflict, for it dismantles Zionism while allowing Israelis to remain in the land and live in the new polity as equal citizens. Its erodes the native/settler dichotomy by proposing the "de-dichotomisation" or "hybridisation" of individual identities. ${ }^{40}$

The binationalists, on the other hand, are concerned with the ethical problems involved in denying different ethnic groups their histories and collective political identities. Like the advocates of the democratic secular state, binationalists reject the ethno-exclusionary character of Zionism. They also agree on the impossibility of partition, given the growth of settlements and the multilayered, unequal interdependence between the colonizer and colonized that Israel produced over the past seventy years. ${ }^{41}$ Binationalists, however, accept the enduring nature of Palestinian and Israeli national identities and recognize the political potency of national markers (language, religion, traditions, et cetera). They acknowledge that both Israelis and Palestinians have collective, not just individual, rights, including a right to selfdetermination. Their central argument is that this right does not need to be territorially conscripted and cannot be fulfilled through partition or in a nation-state. Instead, it can be protected only in a civic state, one that is not ethnically based but is established through a democratic, inclusive process of constitutional selfcreation. The underpinning assumption here is that the state is a juridical order that is accountable to its citizens and responsible for protecting their equality. Such an understanding of the state echoes Hannah Arendt's argument that "our political life rests on the assumption that we can produce equality through organisation." As she put it, "we are not born equal; we become equal members of a group on the strength of our decision to guarantee ourselves mutual equal rights." ${ }^{\text {22 }}$

Binationalists thus consider that the only way forward is for Palestinians and Israelis to come together to create a new organization, or polity, that guarantees their equal collective and individual rights. Only then will it be possible to overcome the political inequalities that both nationalism and colonialism foster. The question then becomes how it could be possible to engage in such a process of decolonization, given the unequal power realities on the ground. Some scholars, including authors in this volume, call for adopting a new framework of analysis, one that focuses on indigeneity or indigenous people's rights as a way to decolonize Israel from within. They are supported by legal scholars using international law to challenge Israel from outside its borders. As discussed by Susan Akram in chapter 8, such a legal strategy emphasizes a civic, rather than an ethnic, definition of nationality, and perceives the state as a juridical order responsible for protecting the equal rights of its citizens. Others emphasize that decolonization is not 
an event but a process that involves decolonizing Israeli-Palestinian relationships, rather than simply the land. According to Bashir and Busbridge, it requires placing Arab-Jewish relations at the center of the decolonization process, allowing "for the narration of Palestinian and Jewish experience in the Middle East alongside each other," rather than at the expense of each other. ${ }^{43}$ Such an approach engages, rather than avoids, the enemy, in order to unravel the intertwined history of the settler and the native. It works through history rather than negates it, both at the local and regional level. It is a process that also seeks to tackle questions concerned with historical reconciliation, national trauma, and transitional justice. ${ }^{44}$

Engaging in such a decolonization process is not easy, especially given the privileges and international immunities that Israelis continue to enjoy today. For most Palestinians, especially for those living under Israel's continuous assault on the Gaza Strip, the West Bank, and East Jerusalem, as much as for those living in refugee camps in the diaspora, it is unrealistic, if not defeatist, to engage a conversation about the rights of Israelis in a future democratic state. It is, however, going to be necessary to identify who could lead such a conversation and how to create a representative platform that articulates the shape of a decolonized polity that would end Palestinian dispossession and provide equality for all. According to Edward Said, it falls on the Palestinians, as unfair as this might sound, since "no people, for bad or for good, is so freighted with multiple, and yet unreachable or indigestible significance as the Palestinians .... Their relationship to Zionism, and ultimately to political and spiritual Judaism, gives them a formidable burden as interlocutors of the Jews." ${ }^{5}$

Decolonizing Palestine would require articulating the components of a new political framework that acknowledges the violence and injustices of the past and the present while prioritizing citizenship rights over territorial sovereignty. It cannot be divorced from the larger struggle within the Arab region, where citizens are defying their oppressive governments, reminding them of their responsibility towards their citizens: to represent rather than oppress them, to honor rather than crush their diversity, and to acknowledge that the acceptance of differences forms the basis of any democratic polity that ensures equality for all.

\section{RETHINKING STATEHOOD}

Rethinking Statehood exposes how Palestinian scholars are redefining the political meaning of decolonization given the end of the historical role the Palestinian state project played for the Palestinian cause. The first part of the book highlights the importance of resituating the Palestinian struggle for liberation within both its regional and its settler-colonial contexts to understand the costs to the Palestinians of remaining confined to the partition paradigm as a means to achieve political independence. The second part exposes the legal and political possibilities in imagining an alternative to partition that protects Palestinian rights. It analyzes how 
the relationship between the nation and the state is being rearticulated to protect both the individual and collective rights of all those living in Israel/Palestine. It also discusses how international law continues to be a powerful instrument to defend Palestinian nationhood. Together, the chapters included here advance a new epistemology of the Israeli-Palestinian conflict, one that sees the Palestinian struggle not solely through the prism of the nation-state or as confined only to Palestinians, but rather enables us to construct a new critical way of thinking about political liberation that allows people to live in equality and dignity, irrespective of their ethnicity.

In chapter 1, Adam Hanieh provides a political economy critique of the Palestinian state project. Hanieh argues that the Palestinian obsession with statehood cannot be understood by remaining confined within a nationalist framework of analysis and without unpacking the political economy of state, and class, formation. He sheds lights on the PNA's institutional role as a facilitator of capital accumulation and highlights the role of regional capital originating in the Arab Gulf states in the development of a Palestinian capitalist class that sustains the Palestinian state project and depends on it. This class, or elite, is supported by a regional and international capitalist system that is key to understanding the obduracy of the status quo, despite it failing the Palestinian people.

Chapter 2 looks more closely at the Gaza Strip as a microcosm of the limitations of the Palestinian state project and the crisis it created, rather than resolved, for the Palestinian national struggle. Tareq Baconi argues that one of the unexpected effects of the Oslo Accords was the split of the Palestinian national movement into two projects: one that adopted the diplomatic route to achieve Palestinian independence, as represented by Fatah and the PNA; the other committed to armed struggle for liberation, albeit in an Islamist guise, as represented by Hamas. Although divisions within the Palestinian movement are not new, the persistence of this political infighting for over fifteen years despite many reconciliation attempts leads to the conclusion that the Palestinian state project is sustained by an elite more interested in power than in national liberation. ${ }^{46}$ Baconi argues that the Gaza Strip has become the lynchpin for determining the future of the Palestinian national movement; its present humanitarian crisis demonstrates the costs of remaining committed to the tenets of Palestinian national liberation and seeking to assert political independence in a context of ongoing colonization.

Chapter 3 provides a micro-picture of how the Palestinian state project disempowered different Palestinian constituencies, denying their political rights and dream of liberation. Hania Assali focuses on East Jerusalem to show how Jerusalem's position as the capital of a future Palestinian state has been undermined by the failure of the PNA to counter Israel's decision to sever the Holy City from the rest of the West Bank. She provides a review of Israel's legal, demographic, and territorial assaults on Palestinians living in East Jerusalem and the ways in which they resist it, as exemplified by the "prayer intifada" in the summer of 2017 and again during Ramadan in April and May 2021. 
Hanan Toukan in chapter 4 touches on the symbolic and aesthetic dimension of the Palestinian state project as represented by the construction of the Palestinian Museum. National museums have typically been markers of national independence. They can thus provide a discursive means to affirm the existence of a people whose history has been denied by the colonizer. The construction of the Palestinian Museum in Birzeit in 2016, however, elicited criticism for being a selective and an elitist endeavor that siphoned money away from more urgent needs. Toukan unpacks the political economy of the Palestinian Museum, arguing that its construction cannot be understood without situating it in a larger regional attempt to shape the discourse around art, identity, and modernity outside the confines of the Western world. Her analysis complements Hanieh's argument in chapter 1 by emphasizing the role of the museum's investors, mostly based in the Gulf and closely tied to the PNA, in seeking to shape the meaning of independence and resistance against Israel's physical, cultural, and economic domination. She shows that the Palestine Museum's political value lies in its temporal orientation, namely its focus on the present. Unlike the Darwish or Arafat museums, which are dedicated to the past and display the contours of the national narrative of dispossession and historical struggle, the Palestinian Museum leaves an open space for engaging the present and rethinking the future. Its architecture reveals an engagement with the continuing reality of dispossession and an attempt to disrupt hegemonic understandings of statehood, peoplehood, space, and time. Whether the Palestinian Museum will succeed in this mission is still to be seen, but so far it shows both the scope and limits of Palestinian agency in a context of ongoing colonization.

Chapter 5 provides a glimpse of the political opportunities that can emerge from resituating the Palestinian cause away from the paradigm of statehood and within a rights discourse instead. Yousef Munayyer in this chapter argues that a political strategy focused on defending Palestinian rights, rather than statehood, is more successful in generating international support today, particularly in the United States. He shows that US support for Palestinians' rights has grown since 2000, highlighting the paradoxical opportunities offered by the Trump era for activists emphasizing Palestinian demands for equality and dignity. Their activism draws on the intersectionality of political struggles, making connection between Trump's and Netanyahu's racist policies to build new international networks of solidarity for the Palestinian people.

Munayyar's analysis provides a segue to the second part of the book, which explores the legal and political dimensions that must be revisited in order to construct a viable political alternative to the current colonial reality. Nadim Khoury in chapter 6 examines the question of transitional justice and the way the Palestinian state project avoided it. He argues that the term has been raised by Palestinian critiques of Oslo to stress the impossibility of peace without providing justice for the full range of Palestinian rights, including the right of return, 
recognition of the Nakba, and an end to the ongoing Israeli violence. The Oslo peace agreements sought to settle the Israeli-Palestinian conflict by sidetracking the question of historical reconciliation. As Khoury demonstrates, the concept of transitional justice could spark new conversations about moving forward but it is also a deeply contested concept since there remain fierce disagreements over whose historical injustices need to be addressed, with what mechanisms, and toward what ends.

Chapter 7 examines how the first Zionist and Palestinian alternatives to partition sought to protect the individual and collective rights of Palestinians and Jews in a single polity. In this chapter, Leila Farsakh examines how early protagonists of a one-state solution conceptualized the notion of the nation and how separate it could be from the state. She also assesses Palestinian and Zionist attempts to incorporate the "other" in their conception of a one-state solution and points to the economic and political challenges that continue to haunt any binational or democratic alternative to partition today.

Chapter 8 focuses on how international law protects Palestinian rights, not only the right of return but also the right to a Palestinian nationality. Susan Akram in this chapter argues that Palestinian nationality is a legally protected concept, despite the Balfour Declaration, the creation of the state of Israel in 1948, and the establishment of the Palestinian Authority in 1995. She unpacks the international legal definition of nationality, which emphasizes the direct relation between a people and a land, rather than the ethnic criteria or a sense of an "imagined community" that sociological use of the term implies. She thereby challenges Israel's denial and elimination of Palestinian nationality in 1948, as well as its creation of a Jewish nationality that is open to all Jews in the world. Akram maintains that Israel's notion of Jewish nationality is not legitimate from an international legal perspective because Israel based it on a religious and extra-territorial definition of the nation. Her analysis suggests that while the concept of Israeli nationality, which presently does not exist and which would bestow equal citizenship rights on both Jews and non-Jews born and living in Israel, would be a legally binding category, Israel's latest nationality law is not. ${ }^{47}$

The legal persistence of the concept of the Palestinian nation has significant ramifications for any post-Oslo political configuration. Mazen Masri in chapter 9 looks more closely at various constitutional frameworks for a single state in historic Palestine. He provides a comparative lens to assess which of the various models of federalism, binationalism, and/or liberal democracy can best protect Palestinian and Israeli individual citizenship rights without compromising their collective or national rights. These rights include not only the freedom to speak one's own language, levy taxes, and elect representatives, but also to acknowledge historical grievances, establish mechanisms for reparation and reconciliation, and decolonize economic and social relations. 
Chapters 10 and 11 meanwhile zoom in on Palestinian citizens in Israel, core constituents of the Palestinian people, to consider how they are rethinking the relationship between the nation and the state in envisaging a political future. Maha Nassar in chapter 10 examines the historical origins and ongoing challenges that Palestinian citizens of Israel confront in trying to both defend their individual and collective rights within Israel and remain part of the Palestinian national movement. She focuses on the evolving positions of Palestinian citizens of Israel in the one-state or two-states debate, exposing the tension they experience between asserting their intrinsic link to the Palestinian national struggle and finding a solution to the Israeli-Palestinian conflict that is politically feasible. Ilan Pappe complements this discussion in chapter 11, where he makes a case for the notion of indigenous sovereignty. He argues that Palestinians citizens of Israel are at the forefront of reclaiming indigeneity as a way to assert the sovereignty of the Palestinian people. Indigenous sovereignty helps resituate the Palestinian struggle within a decolonization paradigm and offers new forms of resistance that challenge the nation-state as a solution.

The conclusion wraps up the book by highlighting some of the line of inquiries that emerge from its chapters and the areas of new research needed to expand our understanding of the meaning and locus of political liberation moving forward.

\section{NOTES}

1. Edward Said, The Question of Palestine (New York: Vintage Books, 1979).

2. Sari Makdisi, Palestine Inside Out: An Everyday Occupation (New York: W.W. Norton \& Company, 2007); Hani Faris, The Failure of the Two-State Solution: The Prospects of One State in the IsraelPalestine Conflict (London: I.B. Tauris, 2013); Mehran Kamrava, The Impossibility of Palestine: History, Geography and the Road Ahead (New Haven, CT: Yale University Press, 2017); Economic and Social Commission for Western Asia, Israeli Practices towards the Palestinian People and the Question of Apartheid (New York: United Nations, 2017).

3. Michael Crowley and David M. Halbfinger, "Trump Releases Mideast Peace Plan That Strongly Favors Israel," The New York Times, January 28, 2020.

4. The Quartet was established in 2002 and includes the United States, European Union, UN, and Russia. Its aim has been to support Oslo peace process and advice the PNA.

5. Ali Abunimeh, One Country: A Bold Proposal to End the Israeli-Palestinian Impasse (New York: Metropolitan Books, 2006); Ali Abunimeh, The Battle for Justice in Palestine (Chicago: Haymarket Press, 2014); Virginia Tilley, The One-State Solution: A Breakthrough for Peace in the Israeli-Palestinian Deadlock (University of Michigan Press, 2005). Benny Morris, One State, Two States: Resolving the Israel/Palestine Conflict (New Haven, CT: Yale University Press, 2010); Hussein Ibish, What's Wrong with the One-State Agenda? Why Ending the Occupation and Peace with Israel is Still the Palestinian National Goal (Washington DC: American Task Force on Palestine, 2009); Gershon Shafir, A Half Century of Occupation: Israel, Palestine and the World's Most Intractable Conflict (Oakland: University of California Press, 2017); Mark LeVine and Mathias Mossberg, One Land, Two States: Israel and Palestine as Parallel States (Berkeley: California University Press, 2014).

6. Beshara Doumani, "Palestine Versus the Palestinians? The Iron Laws and Ironies of a People Denied," Journal of Palestine Studies 36, no. 4 (Summer 2007): 49-64; Ruba Salih and Sophie 
Richter-Devroe, "Palestine beyond National Frames: Emerging Politics, Cultures and Claims," South Atlantic Quarterly 117, no. 1 (2018): 1-20.

7. Said, The Question of Palestine; Fayez Sayigh, Zionist Colonialism in Palestine (Beirut: PLO Research Center, 1965).

8. Joseph Massad, “Against Self-Determination," Humanity Journal 9, no. 2 (2018).

9. Adom Getachew, Worldmaking after Empire: The Rise and Fall of Self-Determination (Princeton, NJ: Princeton University Press, 2019), 74.

10. Getachew, Worldmaking after Empire; Gary Wilder, Freedom Time: Negritude, Decolonization and the Future of the World (Durham, NC: Duke University Press, 2015).

11 See the text of UN Resolution 1514, at http://undocs.org/A/Res/1514(XV).

12. As Wilder put it, "a procedural understanding of self-determination as a people's free choice about its future political status, about a specific framework for self-government, was conflated with a limited understanding of self-determination as state sovereignty for a national group." Wilder, Freedom Time, 88-89.

13. Getachew, Worldmaking after Empire, chapter 3; Wilder, Freedom Time, chapter 4.

14. Said, The Palestine Question, 134.

15. Quoted in Alain Gresh, The PLO: The Struggle Within (London: Zed Books, 1988), 48.

16. See the text of UNSC Resolution 242 at https://www.securitycouncilreport.org/atf/cf/\%7B65 BFCF9 9 -6D 27-4E9 9 -8CD3-CF6E4FF96FF9\%7D/IP\%20S\%2oRES\%20242.pdf.

17. The Arab League recognized the PLO as the sole and legitimate representative of the Palestinian people in a meeting of the Rabat Arab League in June 1974, thus delegitimizing claims by any Arab state to represent the Palestinians. For more details, see Noura Erakat, Justice for Some: Law and the Question of Palestine (Stanford, CA: Stanford University Press, 2019).

18. Yazid Sayigh, Armed Struggle and the Search for State: The Palestinian National Movement 1949-1993, (Oxford: Oxford University Press, 1997). In 1976, the municipal elections that Israel held in the West Bank and Gaza Strip brought to power mayors who were supportive of the PLO.

19. Italics added. See political program adopted at the twelfth session of the Palestinian National Council, in Cairo, June 1974, available at www/pnic.gov/ps/Arabic/semester12.html; my translation.

20. Rashid Khalidi, The Iron Cage: The Story of the Palestinian Struggle for Statehood (Cambridge: Beacon Press, 2007); Gresh, "The PLO and the Naksa."

21. Leila Farsakh, "The 'Right to Have Rights': Partition and Palestinian Self-Determination," Journal of Palestine Studies 47, no. 1 (Fall 2017): 56-68.

22. See PNA, "Palestinian Reform and Development Plan," 2008-10, available at https://www.un .org/unispal/document/auto-insert-208834/; and PNA, "National Development Plan 2011-2013: Establishing the State, Building our Future," available at http://www.mot.gov.ps/wp-content/uploads /Portals/_Rainbow/Documents/Establishing\%2othe\%2oState\%2oBuilding\%2oour\%20Future_\%20 NDP\%202011-13.pdf.

23. The PNA became the largest single employer. Since 2000 it employed 31-48 percent of the total employed labor force in the Gaza Strip and over 15 percent in the West Bank. Central Bureau of Statistics, Statistical Yearbook, Ramallah, various years, available at http://pcbs.gov.ps/PCBS-Metadata -en-v4.3/index.php/catalog/Employment-Unemployment, accessed May 2021.

24. Sophia Stamatopoulou-Robbins, "An Uncertain Climate in Risky Times: How Occupation Became Like the Rain in Post-Oslo Palestine," International Journal of Middle East Studies 50, no. 2 (2018): 383-404, 400.

25. See for example Stamatopoulou-Robbins, "An Uncertain Climate in Risky Times,"; Omar Jabary Salamanca, "Hooked on Electricity: The Charged Political Economy of Electrification in Palestine," paper presented at the first New Direction in Palestine Studies Workshop, Brown University, March 2014; Kareem Rabie, "Housing and the Future of Palestine," paper presented at the New Direction in Palestine Studies Workshop, Brown University, March 2019; and Kareem Rabie, Palestine Is 
Throwing a Party and the Whole World is Invited: Capital and State in the West Bank (Durham, NC: Duke University Press, 2021)

26. For a comprehensive review of the negotiations and their failure, see Shafir, A Half Century of Occupation, George Mitchel and Alon Sachar, A Path to Peace: A Brief History of Israeli-Palestinian Negotiations and a Way Forward in the Middle East (New York: Simon and Schuster, 2016); Khaled Elgindy, Blind Spot: The US and the Palestinians from Balfour to Trump (Washington DC: Brookings Institute, 2019).

27. Michael Keating and Anne Le More, Aid, Diplomacy and Facts on the Ground: The Case of Palestine (London: Chatham House, 2005); Toufic Haddad, Palestine Ltd: Neoliberalism and Nationalism in the Occupied Territories (London: I.B. Tauris, 2016); Linda Tabar, "Disrupting Development, Reclaiming Solidarity: The Anti-Politics of Humanitarianism," Journal of Palestine Studies 45, no. 4 (Summer 2016): 16-31; Alaa Tartir and Timothy Seidel, Palestine and Rule of Power: Local Dissent vs. International Governance (Cham: Palgrave Macmillan, 2019).

28. Leila Farsakh, "Undermining Democracy in Palestine: The Politics of International Aid since Oslo," Journal of Palestine Studies 45, no. 4 (Summer 2016).

29. Farsakh, "Undermining Democracy in Palestine"; Tabar, "Disrupting Development."

30. Jamil Hilal, Where Now for Palestine? The Demise of the Two-State Solution, (London: Zed Books, 2006); Jamil Hilal, "Rethinking Palestine: Settler-Colonialism, Neo-liberalism and Individualism in the West Bank and Gaza Strip," Contemporary Arab Affairs 8, no. 3 (July-September 2015).

31. Ariella Azoulay and Adi Ophir, The One-State Condition: Occupation and Democracy in Israel/ Palestine (Stanford, CA: Stanford University Press, 2012); Leila Farsakh, ed., "Commemorating the Naksa, Evoking the Nakba," special issue, Electronic Journal of Middle Eastern Studies 8 (Spring 2008); Omar Barghouti, Boycott, Divestment, Sanctions: The Global Struggle for Palestinian Rights (Chicago: Haymarket Press, 2011); Virginia Tilley, "After Oslo, a Paradigm Shift? Redefining Sovereignty, Responsibility and Self-determination," Conflict, Security and Development 15, no. 5 (2015): 425-53; Economic and Social Commission for Western Asia, Israeli Practices.

32. See for example the latest annual report of the Jerusalem Legal and Aid Center, http://www .jlac.ps/userfiles/file/Annual_Reports/AnRep2018.pdf; Human Rights Watch Report, Two Authorities, One Way, Zero Dissent: Arbitrary Arrest and Tortures Under the Palestinian Authority and Hamas, https://www.hrw.org/report/2018/10/23/two-authorities-one-way-zero-dissent/arbitrary-arrest-and -torture-under.

33. Arie Dubonov and Laura Robson, Partition: A Transnational History of Twentieth-Century Separatism (Stanford, CA: Stanford University Press, 2019).

34. Salih and Richeter-Devroe, "Palestine beyond National Frames," 8.

35. See among others, Lorenzo Veracini, "The Other Shift: Settler Colonialism, Israel and the Occupation," Journal of Palestine Studies 42, no. 2 (2013): 26-42; Omar Salamanca, Mazna Qato, and Kareem Rabie, "The Past Is Present: Settler Colonialism in Palestine," Settler Colonial Studies 2, no. 1 (2012): 1-8; Francesco Amoruso, Ilan Pappe, and Sophie Richter-Devroe, "Introduction: Knowledge, Power, and the 'Settler Colonial Turn' in Palestine Studies," Interventions: The International Journal of Postcolonial Studies 21, no. 4 (2019): 451-63.

36. Hazem Jamjoum, "Reclaiming the Political Dimension of the Palestinian Narrative," Al-Shabaka: The Palestinian Policy Network, September 12, 2018, https://al-shabaka.org/circles/reclaiming -the-political-narrative-in-palestinian-politics/.

37. Amoruso, Pappe, and Richter-Devroe, "Introduction"; Rana Barakat, "Writing/Righting Palestine Studies: Settler Colonialism, Indigenous Sovereignty and Resisting the Ghost(s) of History," Settler Colonial Studies 8, no. 3 (2018): 349-63; Salih and Richter-Devroe, "Palestine beyond National Frames."

38. Abumineh, Battle for Justice in Palestine; Bashir Bashir, "The Strengths and Weaknesses of Integrative Solutions for the Israeli-Palestinian Conflict," Middle East Journal 70, no. 4 (2016): 560-78; 
Faris, Failure of the Two-State Solution; Leila Farsakh, "The One-State Solution and the Israeli-Palestinian Conflict: Palestinian Challenges and Prospects," Middle East Journal 65, no. 1 (2011): 55-71.

39. Abunimeh, The Battle for Justice in Palestine; Omar Barghouti, "The Secular Democratic State Is the Only Possible and Ideal Solution," Journal of Palestine Studies 76 (2008): 8-25 [Arabic].

40. Omar Barghouti, “The Secular Democratic State."

41. Nadim Rouhana, Israel and its Palestinian Citizens: Ethnic Privileges in the Jewish State (Cambridge: Cambridge University Press, 2017); Asa'ed Ghanem, “The Bi-National State Solution,” Israel Studies 14, no. 2 (Summer 2009): 120-33; Farsakh, “The One-State Solution;” Bashir, “The Strengths and Weaknesses of Integrative Solutions."

42. Hannah Arendt, The Origins of Totalitarianism (New York: Harcourt, Brace and Jovanovich, 1968 [1951]), 301.

43. Bashir Bashir and Rachel Busbridge, "The Politics of Decolonization and Bi-Nationalism in Israel/Palestine," Political Studies 67, no. 2 (2019): 388-405.

44. Bashir Bashir and Amos Goldberg, The Holocaust and the Nakba (New York: Columbia University Press, 2019).

45. Said, The Question of Palestine, 122.

46. The periods of infighting were: between 1983 and 1986, during the camp wars in Lebanon and the split of Fatah, and between 1996 and 1999, during the PNA/Fatah assault on Hamas, which did not lead to a severance between the two political parties.

47. Israel offers Israeli citizenship to both Jews and non-Jews. Israel defines nationality on the basis of the religious affiliation of its citizens, for example, Jewish nationality, Christian nationality, Muslim nationality, or Druze nationality. For an excellent analysis and a genealogy of Israel's legal separation of citizenship from nationality as a way to protect the notion of a Jewish, versus Israeli, nationality, see Shira Robinson, Citizen Strangers: Palestinians and the Birth of Israel's Liberal Settler State (Stanford, CA: Stanford University Press, 2013).

\section{BIBLIOGRAPHY}

Abunimeh, Ali. The Battle for Justice in Palestine. Chicago: Haymarket Press, 2014. . One Country: A Bold Proposal to End the Israeli-Palestinian Impasse. New York: Metropolitan Books, 2006.

Amoruso, Francesco, Ilan Pappe, and Sophie Richter-Devroe. "Introduction: Knowledge, Power, and the 'Settler Colonial Turn' in Palestine Studies." Interventions: The International Journal of Postcolonial Studies 21, no. 4 (2019): 451-63.

Arendt, Hannah. The Origins of Totalitarianism. New York: Harcourt, Brace and Jovanovich, 1968 [1951].

Azoulay, Ariella, and Adi Ophir. The One-State Condition: Occupation and Democracy in Israel/Palestine. Stanford, CA: Stanford University Press, 2012.

Barakat, Rana. "Writing/Righting Palestine Studies: Settler Colonialism, Indigenous Sovereignty and Resisting the Ghost(s) of History." Settler Colonial Studies 8, no. 3 (2018): 349-63.

Barghouti, Omar. Boycott, Divestment, Sanctions: The Global Struggle for Palestinian Rights. Chicago: Haymarket Press, 2011.

—. "The Secular Democratic State Is the Only Possible and Ideal Solution." Journal of Palestine Studies 76 (2008): 8-25. [Arabic.]

Bashir, Bashir. "The Strengths and Weaknesses of Integrative Solutions for the IsraeliPalestinian Conflict." The Middle East Journal 70, no. 4 (2016): 560-78. 
Bashir, Bashir, and Rachel Busbridge. "The Politics of Decolonization and Bi-Nationalism in Israel/Palestine." Political Studies 67, no. 2 (2019): 388-405.

Bashir, Bashir, and Amos Goldberg. The Holocaust and the Nakba: A New Grammar of Trauma and History. New York: Columbia University Press, 2019.

Busbridge, Rachel. "Israel-Palestine and the Settler Colonial 'Turn': From Interpretation to Decolonization." Theory, Culture and Society 35, no. 1 (2018): 91-115.

Doumani, Beshara. "Palestine Versus the Palestinians? The Iron Laws and Ironies of a People Denied." Journal of Palestine Studies 36, no. 4 (2007): 49-64.

Dubonov, Arie, and Laura Robson. Partition: A Transnational History of Twentieth-Century Separatism. Stanford, CA: Stanford University Press, 2019.

Economic and Social Commission for Western Asia. Israeli Practices towards the Palestinian People and the Question of Apartheid. New York: United Nations, 2017.

Elgindy, Khaled. Blind Spot: The US and the Palestinians from Balfour to Trump. Washington, DC: Brookings Institute, 2019.

Erakat, Noura. Justice for Some: Law and the Question of Palestine. Stanford, CA: Stanford University Press, 2019.

Faris, Hani. The Failure of the Two-State Solution: The Prospects of One State in the IsraelPalestine Conflict. London: I.B. Tauris, 2013.

Farsakh, Leila, ed. Commemorating the Naksa, Evoking the Nakba. Special issue, Electronic Journal of Middle Eastern Studies 8 (2008).

. "The One-State Solution and the Israeli-Palestinian Conflict: Palestinian Challenges and Prospects." Middle East Journal 64, no.1 (2011): 20-45.

—. "The Right to Have Rights: Partition and Palestinian Self-Determination." Journal of Palestine Studies 47, no. 1 (2017): 56-68.

- "Undermining Democracy in Palestine: The Politics of International Aid since Oslo." Journal of Palestine Studies 45, no. 4 (2016): 48-63.

Getachew, Adom. Worldmaking after Empire: The Rise and Fall of Self-Determination. Princeton, NJ: Princeton University Press, 2019.

Ghanem, Asa'ed. “The Bi-National State Solution.” Israel Studies 14, no. 2 (2009): 120-33.

Gresh, Alain. The PLO: The Struggle Within. London: Zed Books, 1988.

- "The PLO and the Naksa: The Search for a Palestinian State." Electronic Journal of Middle Eastern Studies 8 (Spring 2008): 81-93.

Haddad, Toufic. Palestine Ltd: Neoliberalism and Nationalism in the Occupied Territories. London: I.B. Tauris, 2016.

Hilal, Jamil. "Rethinking Palestine: Settler-Colonialism, Neo-liberalism and Individualism in the West Bank and Gaza Strip." Contemporary Arab Affairs 8, no. 3 (2015): 351-62.

- ed. Where Now for Palestine? The Demise of the Two-State Solution. London: Zed Books, 2006.

Ibish, Hussein. What's Wrong with the One-State Agenda? Why Ending the Occupation and Peace with Israel Is Still the Palestinian National Goal. Washington DC: American Task Force on Palestine, 2009.

Jamal, Amal. Arab Minority Nationalism in Israel: The Politics of Indigeneity. London: Routledge Press, 2011.

Kamrava, Mehran. The Impossibility of Palestine: History, Geography and the Road Ahead. New Haven, CT: Yale University Press, 2017. 
Keating, Michael, and Anne Le More, eds. Aid, Diplomacy and Facts on the Ground: The Case of Palestine. London: Chatham House, 2005.

Khalidi, Rashid. The Iron Cage: The Story of the Palestinian Struggle for Statehood. Cambridge, MA: Beacon Press, 2007.

LeVine, Mark, and Mathias Mossberg. One Land, Two States: Israel and Palestine as Parallel States. Berkeley: California University Press, 2014.

Makdisi, Sari. Palestine Inside Out: An Everyday Occupation. New York: W. W. Norton \& Company, 2007.

Massad, Joseph. “Against Self-Determination.” Humanity Journal 9, no. 2 (2018): 161-91.

Mitchel, George, and Alon Sachar. A Path to Peace: A Brief History of Israeli-Palestinian Negotiations and a Way Forward in the Middle East. New York: Simon and Schuster, 2016.

Morris, Benny. One State, Two States: Resolving the Israel/Palestine Conflict. New Haven, CT: Yale University Press, 2010.

Nassar, Maha. Brothers Apart: Palestinian Citizens of Israel and the Arab World. Stanford, CA: Stanford University Press, 2017.

Pace, Michelle, and Sen Somdeep. The Palestinian Authority in the West Bank: The Theatrics of Woeful Statecraft. New York: Routledge, 2019.

Pappe, Ilan. The Forgotten Palestinians: A History of the Palestinians in Israel. New Haven, CT: Yale University Press, 2011.

- ed. Israel and South Africa: The Many Faces of Apartheid. London: Zed Books, 2015. Rabie, Kareem. "Housing and the Future of Palestine." Paper presented at the New Direction in Palestine Studies Workshop, Brown University, March 2019.

Robinson, Shira. Citizen Strangers: Palestinians and the Birth of Israel's Liberal Settler State. Stanford, CA: Stanford University Press, 2013.

Rouhana, Nadim. "Decolonization as Reconciliation: Rethinking the National Conflict Paradigm in the Israeli-Palestinian Conflict." Journal of Ethnic and Racial Studies 41, no. 4 (2018): 643-62.

— ed. Israel and its Palestinian Citizens: Ethnic Privileges in the Jewish State. Cambridge: Cambridge University Press, 2017.

Said, Edward. The Question of Palestine. New York: Vintage Books, 1979.

Salamanca, Omar Jabary. "Hooked on Electricity: The Charged Political Economy of Electrification in Palestine." Paper presented at the New Direction in Palestine Studies Workshop, Brown University, March 2014.

Salamanca, Omar, Mazna Qato, and Kareem Rabie. “The Past Is Present: Settler Colonialism in Palestine." Settler Colonial Studies 2, no. 1 (2012): 1-8.

Salih, Ruba, and Sophie Richter-Devroe. "Palestine beyond National Frames: Emerging Politics, Cultures and Claims." South Atlantic Quarterly 117, no. 1 (2018): 1-20.

Sayigh, Fayez. Zionist Colonialism in Palestine. Beirut: PLO Research Center, 1965.

Sayigh, Yazid. Armed Struggle and the Search for State: The Palestinian National Movement 1949-1993. Cambridge: Cambridge University Press, 1997.

Shafir, Gershon. A Half Century of Occupation: Israel, Palestine and the World's Most Intractable Conflict. Oakland: University of California Press, 2017.

Stamatopoulou-Robbins, Sophia. "An Uncertain Climate in Risky Times: How Occupation Became Like the Rain in Post-Oslo Palestine." International Journal of Middle East Studies 50, no. 3 (2018): 383-404. 
Tabar, Linda. "Disrupting Development, Reclaiming Solidarity: The Anti-Politics of Humanitarianism." Journal of Palestine Studies 45, no. 4 (2016): 16-31.

Tartir, Alaa, and Timothy Seidel. Palestine and Rule of Power: Local Dissent vs. International Governance. Cham: Palgrave Macmillan, 2019.

Tilley, Virginia. "After Oslo, a Paradigm Shift? Redefining Sovereignty, Responsibility and Self-determination." Conflict, Security and Development 15, no. 5 (2015): 4252-53.

- The One-State Solution: A Breakthrough for Peace in the Israeli-Palestinian Deadlock. Ann Arbor: University of Michigan Press, 2005.

Veracini, Lorenzo. "The Other Shift: Settler Colonialism, Israel and the Occupation." Journal of Palestine Studies 42, no. 2 (Winter 2013): 26-42.

Wilder, Gary. Freedom Time: Negritude, Decolonization and the Future of the Work. Durham, NC: Duke University Press, 2015. 